\begin{tabular}{|c|c|c|c|}
\hline \multirow{2}{*}{$\Omega$} & \multirow{2}{*}{ ENGINEERING CHANGE NOTICE } & \multirow{2}{*}{ Page 1 of 2} & 1. ECN $\quad 652922$ \\
\hline & & & $\begin{array}{l}\text { Proj. } \\
\text { ECN }\end{array}$ \\
\hline
\end{tabular}

\begin{tabular}{|c|c|c|c|c|}
\hline $\begin{array}{l}\text { 2. ECN Category } \\
\text { (mark one) } \\
\text { Supplemental }\end{array}$ & [] & $\begin{array}{l}\text { 3. Originator's Name, Organization, MSIN, and } \\
\text { Telephone No. } \\
\text { KD Hein } 08 \mathrm{E} 00 \quad \mathrm{~S} 7-12 \quad 6-1573 \\
\end{array}$ & $\begin{array}{l}\text { 4. USQ Required? } \\
{[\mathrm{X}] \text { Yes [] No }}\end{array}$ & $\begin{array}{l}\text { 5. Date } \\
\qquad 11 / 19 / 99 \\
\end{array}$ \\
\hline $\begin{array}{l}\text { Direct Revision } \\
\text { Change ECN } \\
\text { Temporary }\end{array}$ & {$[\mathrm{X}]$} & $\begin{array}{l}\text { 6. Project Title/No./Work Order No. } \\
\text { Characterization Project / CACN } 102250\end{array}$ & $\begin{array}{l}\text { 7. Bldg./Sys./Fac. No. } \\
200 \mathrm{G}\end{array}$ & $\begin{array}{l}\text { 8. Approval Designator } \\
\text { N/A }\end{array}$ \\
\hline $\begin{array}{l}\text { Standby } \\
\text { Supersedure } \\
\text { Cancel/Void }\end{array}$ & [] & $\begin{array}{l}\text { 9. Document Numbers Changed by this ECN } \\
\text { (includes sheet no. and rev.) } \\
\text { HNF-SD-WM-ETP-220, REV OB }\end{array}$ & $\begin{array}{l}\text { 10. Related } \mathrm{ECN} \mathrm{No}(\mathrm{s}) \text {. } \\
\text { N/A }\end{array}$ & $\begin{array}{l}\text { 11. Related PO No. } \\
\text { N/A }\end{array}$ \\
\hline
\end{tabular}

\begin{tabular}{|c|c|c|c|}
\hline $\begin{array}{l}\text { 12a. Modification Work } \\
\text { [] Yes (fill out Blk. 12b) }\end{array}$ & $\begin{array}{l}\text { 12b. Work Package } \\
\text { No. }\end{array}$ & $\begin{array}{l}\text { 12c. Modification Work Complete } \\
\text { N/A }\end{array}$ & $\begin{array}{l}\text { 12d. Restored to Original Condition (Temp. } \\
\text { or Standby ECN only) } \\
\text { N/A }\end{array}$ \\
\hline $\begin{array}{c}{[X] \text { No (NA Blks. 12b, }} \\
12 \mathrm{c}, 12 \mathrm{~d})\end{array}$ & N/A & $\begin{array}{l}\text { Design Authority/Cog. Engineer } \\
\text { Signature \& Date }\end{array}$ & $\begin{array}{l}\text { Design Authority/Cog. Engineer } \\
\text { Signature \& Date }\end{array}$ \\
\hline
\end{tabular}

This ECN changes the Engincering Task Plan Routine Enginecring Support for Core Sampler Systems, WHC-SD-WMETP-220, Rev 0B. The revision of WHC-SD-WM-ETP-220 is changed from Rev 0B to Rev 1.

This ECN incorporates simple wording changes to pages 1-5, and implements changes to reflect the new ETP format dictated by desk instructions and new pages 6 and 7 will be added to accommodate the new ETP format.

This ECN also changes WHC-SD-WM-ETP-220 to more closely reflect current day practices performed by Characterization Engineering group.

\begin{tabular}{|lllllll}
\hline 14a. Justification (mark one) & & & & \\
Criteria Change & {$[\mathrm{x}]$} & Design Improvement & {[]} & Environmental & {[]} & Facility Deactivation \\
As-Found & {[]} & Facilitate Const & {[]} & Const. Error/Omission & {[]} & Design Error/Omission [] \\
\hline
\end{tabular}

14b. Justification Details

- The changes to Pages 1-5 are rewording for clarification only and to produce the new ETP format required by desk instructions. A new Page 6 and 7 will be added to produce the new ETP format.

- This Design will not result in exposure change $>1$ person REM (Whole Body) or $>10$ person REM (Extremities) for the installation, maintenance and operation of the life of the modification.

- The changes implemented by this ECN constitute administrative changes only. Therefore, a NEPA screen is not required, per Section 2.1 of 1 NNFPRO-452.

- This ECN is covered by USQ\#TF-96-0690, Rev 2

15. Distribution (include name, MSIN, and no. of copies)

$\begin{array}{llllll}\text { R. N. Dale } & \$ 7-12 & 1 \text { COPY } & \text { E. E. Salinas } & 57-12 & 1 \text { COPY } \\ \text { G. P. Janicek } & \$ 7-12 & 1 \text { COPY } & \text { G. W. Wilson } & \text { S7-12 } & 1 \text { COPY } \\ \text { K. D. Hein } & \$ 7-12 & 1 \text { COPY } & \text { A. B. Cockrell } & \text { S7-12 } & 1 \text { COPY }\end{array}$

J. L. Logston $\quad \$ 7-07 \quad 1$ COPY

G. W. Wilson

S7-12

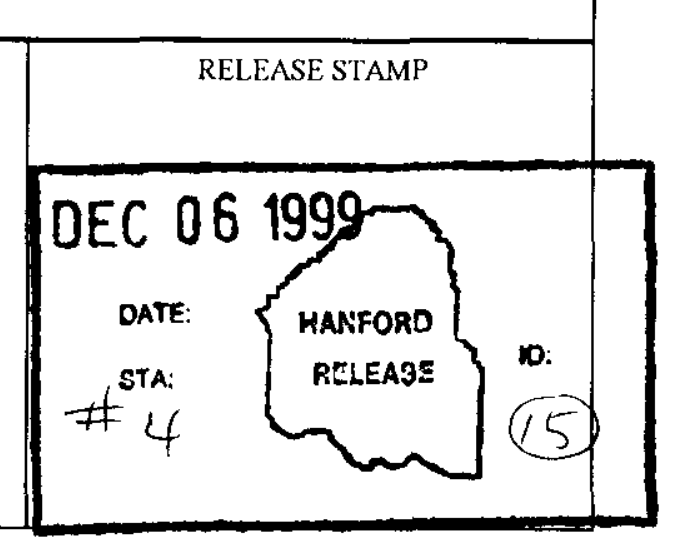




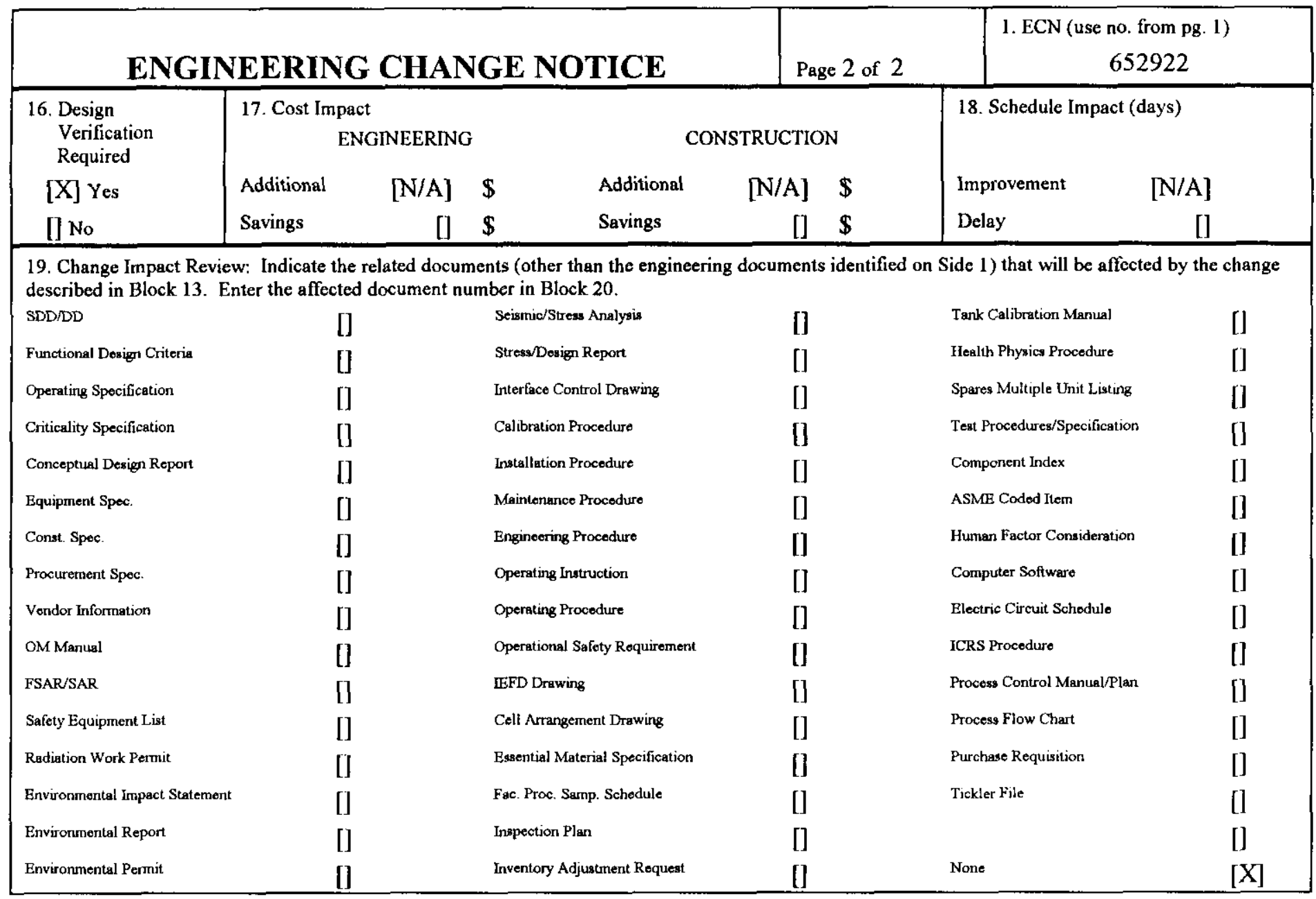

20. Other Affected Documents: (NOTE: Documents listed below will not be revised by this ECN.) Signatures below indicate that the signing organization has been notified of other affected documents listed below.
Document Number/Revision
Document Number/Revision
Document Number Revision
N/A
N/A
N/A

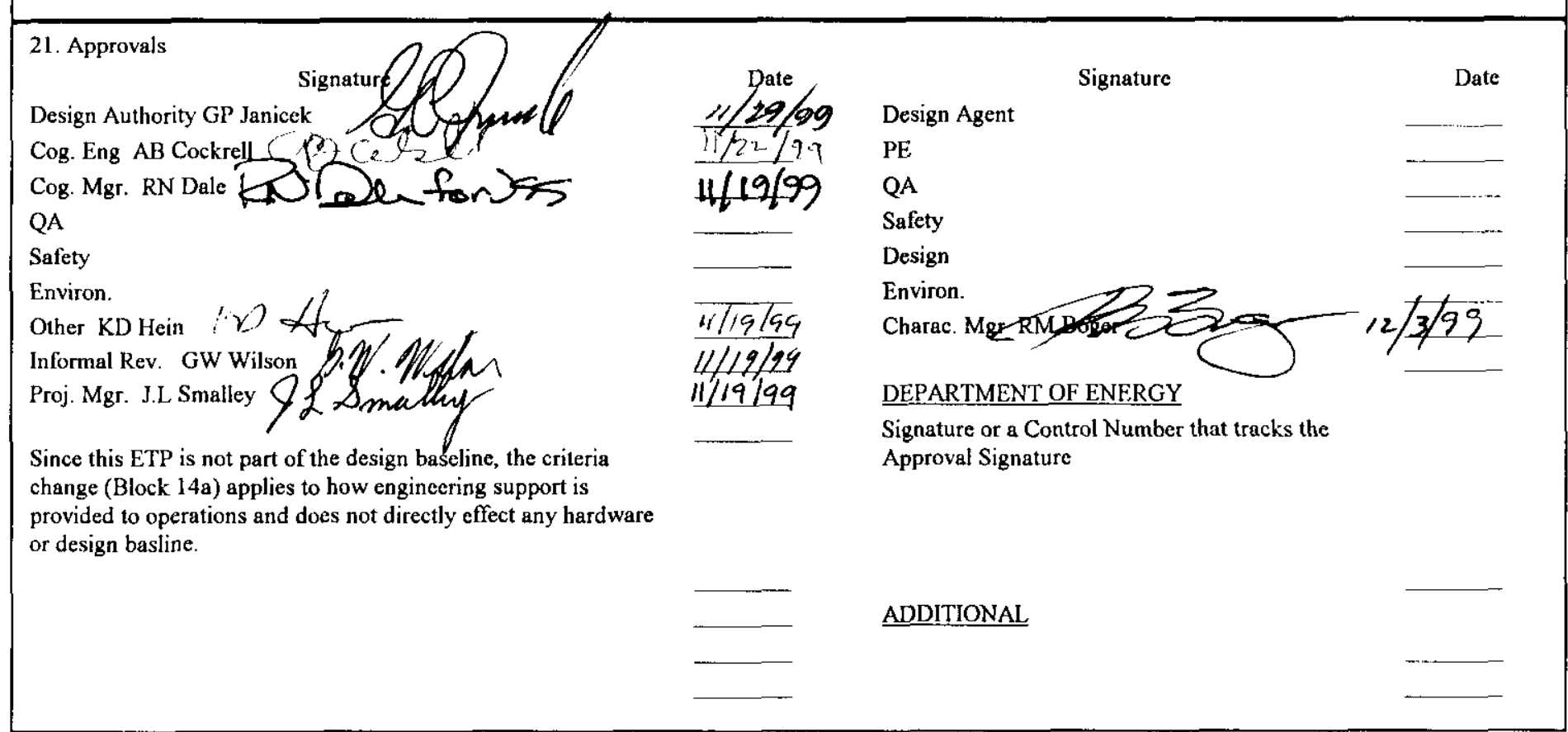


HNF-SD-WM-ETP-220, Rev. I

$\Omega$

\section{ENGINEERING TASK PLAN}

RM Boger

Prepared by Lockheed Martin Hanford Corp.

Richland, WA 99352

U.S. Department of Energy Contract DE-AC06-96RL13200

EDT/ECN: 619141

Org Code: 74900

B\&R Code: EW3120074
UC: 2070

Charge Code: 102250/B000

Total Pages: 711 (JKB 12/6/99)

Key Words: Operations, Routine Engineering Support,

Abstract: This Engineering Task Plan (ETP) is the management plan document for providing routine engineering support for Characterization Project Operations.

TKADEMARK DISCLAJMER. Reference therein to any speciffe commercial produet, proctss, or sCrvice by trade name, trademark, manufacturer, or otherwise, does not necessarily constitute or imply its endorsement, recommendation, or favoring by the United States Government or any agency thereof or its contractors or subcontractors.

Printed in the United States of America. To obtain copies of this document, contact: Document Control Services, P.O. Box 950, Mailstop H6-08, Richland WA 99352, Phone (509) 372-2420; Fax (509) 376-4989.

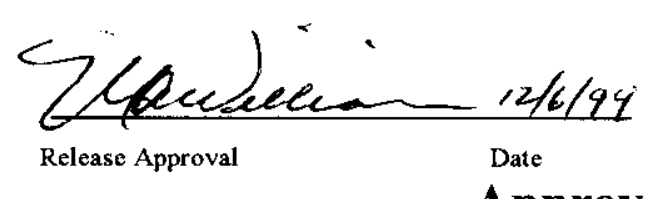

A-6400-073 (01/97) GEF321

DEC 06 1998

DATE:

gTa. 44 roLCASE

Release Stamp
10:

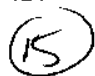




\begin{tabular}{|c|c|c|c|c|}
\hline \multicolumn{2}{|r|}{ RECORD OF REVISION } & \multicolumn{2}{|c|}{$\begin{array}{l}\text { (1) Document Number } \\
\text { HNF-SD-WM-ETP-220 }\end{array}$} & Page 1 \\
\hline \multicolumn{5}{|c|}{ (2) Title ENGINEERING TASK PLAN FOR ROUTINE ENGINEERING SUPPORT FOR CORE SAMPLER TRUCKS } \\
\hline \multicolumn{5}{|c|}{ CHANGE CONTROL RECORD } \\
\hline \multirow[t]{2}{*}{ (3) Revision } & \multirow[t]{2}{*}{ (4) Description of Change - Replace, Add, and Delete Pages } & \multicolumn{3}{|c|}{ Authorized for Release } \\
\hline & & (5) Cog. Engr. & (6) $\operatorname{Cog}$ & Date \\
\hline 0 & INITIAL RELEASE EDT 619141 & RN DALE & J.S. Sc & ield $08 / 18 / 98$ \\
\hline $0 \mathrm{~A}$ & ADD PAGES 7-11 PER ECN 647500 & $\begin{array}{l}\mathrm{AB} \\
\text { COCKRELL }\end{array}$ & J.S. Sc & ield 08/6/98 \\
\hline OB & .ADD PAGES 12-15 PER ECN 650925 & EJ WALDO & \begin{tabular}{|l} 
J.S. Sc \\
$1 / 12 / 9$ \\
\end{tabular} & \\
\hline $\begin{array}{ll}1 \\
\text { RS }\end{array}$ & $\begin{array}{l}\text { COMPLETE REVISION TO UPDATE DOCUMENT TO } \\
\text { INCLUDE NEW REQUIREMENTS AND PROCEDURES. } \\
\text { Per ECN }-652922 \quad \text { (J/CB } 12 / 6 / 99\end{array}$ & $\begin{array}{l}\text { AB } C \text { P } \\
\text { COCKRELL } \\
11 / 24 / 99\end{array}$ & RN & Atoriss \\
\hline & & & & \\
\hline & & & & \\
\hline & & & & \\
\hline & & & & \\
\hline & & & & \\
\hline & & & & \\
\hline & & & & \\
\hline & & & & \\
\hline & & & & \\
\hline & & & & \\
\hline & & & & \\
\hline & & & & \\
\hline & & & & \\
\hline & & & & \\
\hline & & & & \\
\hline & & & & \\
\hline & & & & \\
\hline & & & & \\
\hline & & & & \\
\hline & & & & \\
\hline
\end{tabular}




\title{
ENGINEERING TASK PLAN FOR ROUTINE ENGINEERING SUPPORT FOR CORE SAMPLER SYSTEMS
}

\author{
Prepared for \\ Lockheed Martin Hanford Corporation \\ Characterization Engineering Group \\ Richland, Washington
}

\author{
By \\ K. D. Hein \\ COGEMA Engineering Corp.
}

November, 1999 


\section{TABLE OF CONTENTS}

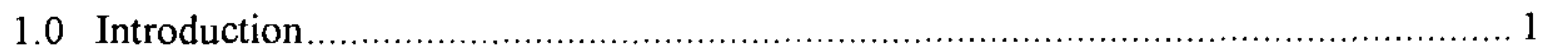

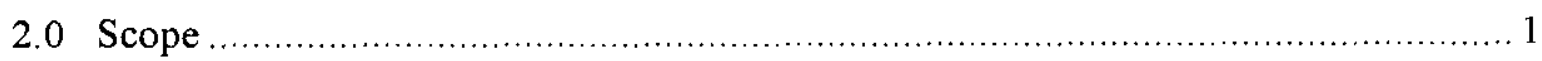

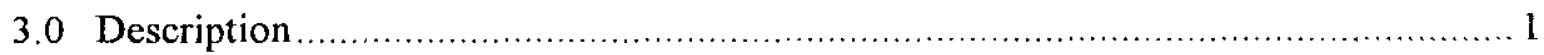

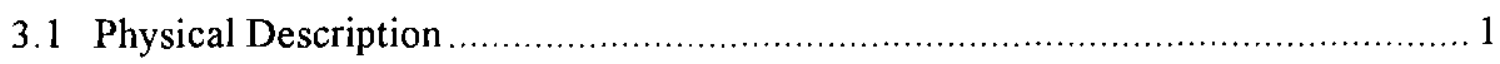

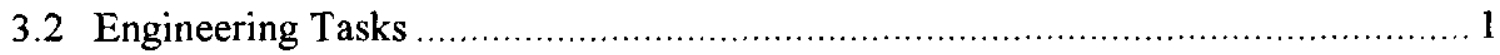

3.3 Verification and Technical Reviews and Modification Management ................. 2

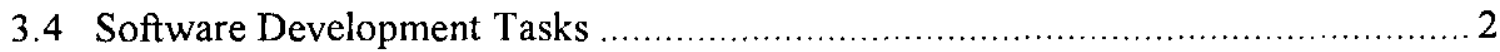

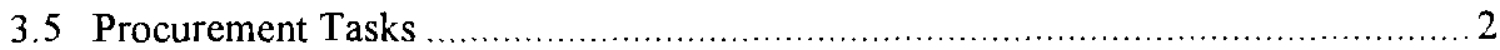

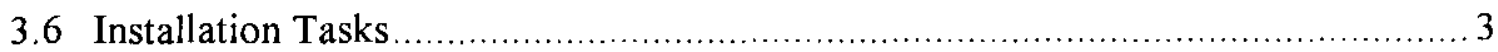

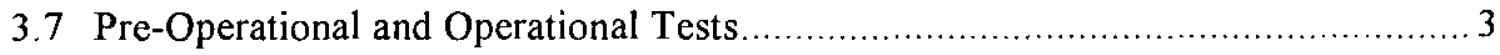

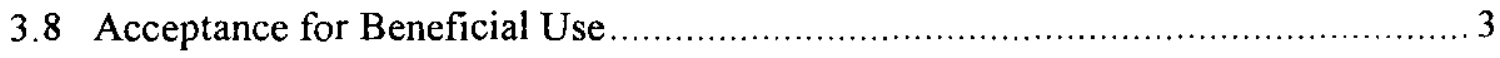

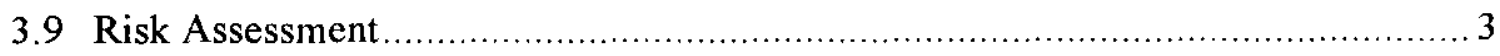

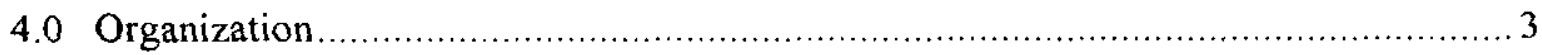

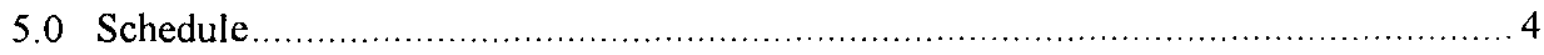

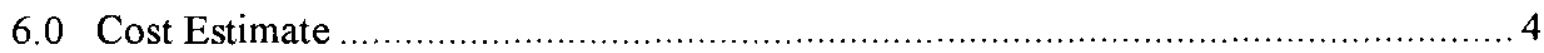

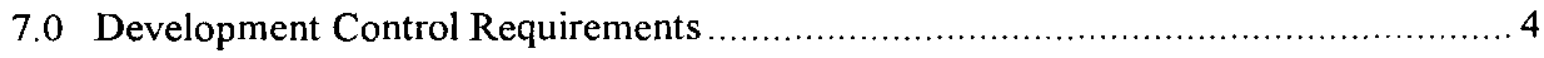

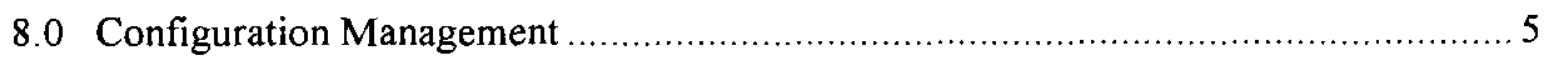

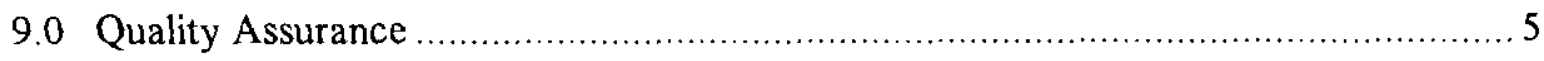

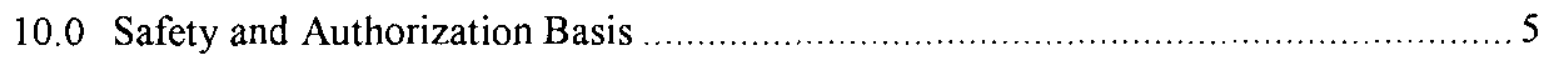

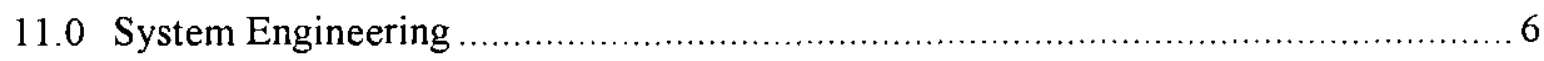

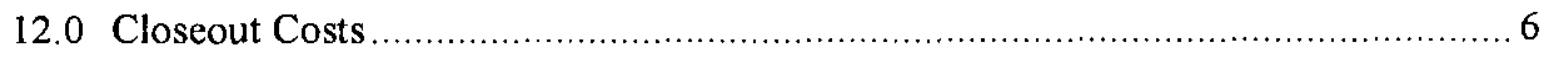

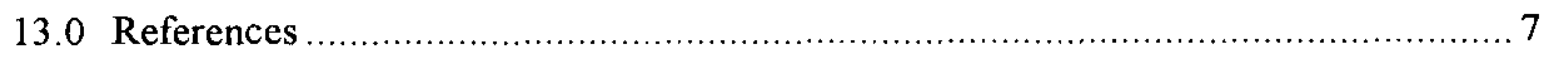

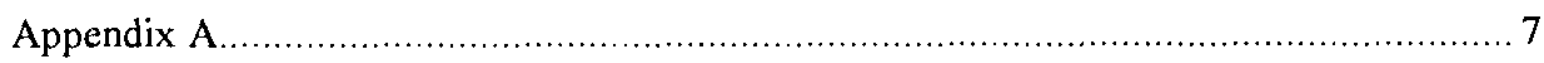

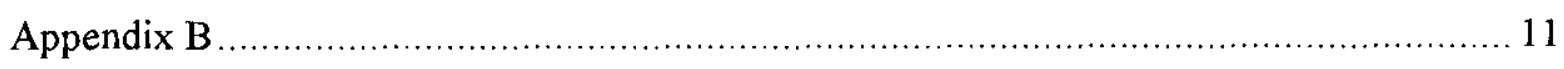




\subsection{INTRODUCTION}

Routine engineering support is required during normal operation of the core sampler trucks and associated ancillary equipment. This engineering support consists of, but is not limited to, troubleshooting operation problems, correcting minor design problems, assistance with work package preparation, assistance with procurement, fabrication shop support, planning of engineering tasks and preparation of associated Engineering Task Plans (ETP) and Engineering Service Requests (ESR).

This ETP is the management plan document for implementing routine engineering support. Any additional changes to the scope of this ETP shall require a Letter of Instruction from Lockheed Martin Hanford Corp (LMHC).

This document will also be the Work Planning Document for Development Control (HNF 1999a).

\subsection{SCOPE}

The scope of this task will be to provide routine engineering support for Characterization equipment as required to support Characterization Operations.

A task by task decision will be made by management to determine which tasks will be done per this ETP and if additional ETPs and /or ESRs are required.

Due to the unique nature of this task, the only identifiable deliverable is to provide support as requested. Deliverables will be recorded in a task logbook as activities are identified. ESRs will be generated for tasks that require more than 40 person hours to complete, per Characterization Engineering Desk Instructions (DI 1999a).

\subsection{DESCRIPTION}

\subsection{PHYSICAL DESCRIPTION}

This task will be for routine engineering support for day to day operations of characterization sampling systems that are utilized by Characterization Operations.

\subsection{ENGINEERING TASKS}

Engineering tasks include, but will not be limited to, the following:

- Generating ETPs and ESRs for tasks as required

- Generating estimates as required

- Troubleshooting of equipment operational problems 
- Support for routine maintenance

- Generating Engineering Change Notices (ECN) to correct minor design problems

- Generating ECNs for minor reliability/operability improvements

- Generating ECNs for special tools

- Generating Unreviewed Safety Question Screenings (USQ) for associated ECNs

- Assisting Characterization Production Control with work package preparation

- Provide field support during installation of equipment modifications

- Providing Fabrication Services support during fabrication of parts and special tools

- Providing support for procurement of spares or replacement parts, including CGI form preparation.

- Completing closeout activities, Acceptance For Beneficial Use (ABU) or J-6s.

Engineering tasks will also include maintaining a task logbook, where requests for engineering support and resultant actions and deliverables will be documented. The logbook will be reviewed with operations periodically to establish priorities of each activity.

All subsequent design media and engineering documentation shall reference engineering task number ETN-97-0013, and any applicable numeric suffix.

\subsection{VERIFICATION AND TECHNICAL REVIEWS AND MODIFICATION MANAGEMENT}

Design verification of changes will be determined on a task by task basis per Design Verification (HNF 1999b). All changes will be reviewed and approved by the Design Authority for applicable verification method.

Due to the nature of these engineering tasks, the design criteria for these activities will either be existing criteria or will be determined during task scoping and will be recorded as part of this ECN.

\subsection{SOFTWARE DEVELOPMENT TASKS}

There are no identified software development tasks associated with this task plan.

\subsection{PROCUREMENT TASKS}

Procurement tasks will be limited to required hardware for minor changes and support for procurement of spares or replacement parts. All procurements will be done by a LMHC Material Coordinator. 


\subsection{INSTALLATION TASKS}

Installation Support for installation of minor design modifications and maintenance activities is included in this task plan. This support will include modification closeout documentation.

\subsection{PRE-OPERATIONAL AND OPERATIONAL TESTS}

Pre-operational testing of modifications and other maintenance activities will be specified and performed as part of the maintenance work package and will be approved by Characterization Cognizant Engineers.

If more rigorous testing is required as determined by engineering or the project manager, a Test Procedure will be written per Testing Practices Requirements, (HNF 1999c).

\subsection{ACCEPTANCE FOR BENEFICIAL USE}

Engineering support will be provided to accommodate the ABU process, as applicable, for this task, per Acceptance of Structures, Systems and Components for Beneficial Use, (HNF 1999d).

\subsection{RISK ASSESSMENT}

Risks associated with this activity shall be assessed on a task-by-task basis.

\subsection{ORGANIZATION}

Responsibilities are assigned to various organizations as identified below:

COGEMA Engineering Corporation will provide task management, engineering support and design services support.
Responsible Manager:
J. L. Smalley

Lockheed Martin Hanford Corporation (LMHC) will provide funding and overall task management, Cognizant Engineer support for document review and Un-reviewed Safety Question (USQ) screening preparation, and Design Authority support.
Responsible Manager:
R. M. Boger
Responsible Cognizant Manager:
J. S. Schofield
Responsible Cognizant Engineer:
R. N. Dale
Characterization Project Design Authority:
G. P. Janicek 
Characterization Production Control will be responsible for generating installation work packages

Responsible Person: B L Debban

Characterization Maintenance will be responsible for providing craft for installation work.

Responsible Person: BJ Shoemake

\subsection{SCHEDULE}

This task is an ongoing task with an end date of September 30,2000. Schedules and priorities will be established for each separate task by agreement with Operations and Maintenance.

\subsection{COST ESTIMATE}

Costs shall be determined on a task-by-task basis. The overall budget for this activity as shown in the Multi-year Work Plan (MYWP) (HNF 1999f) is $\$ 850 \mathrm{k}$.

\subsection{DEVELOPMENT CONTROL REQUIREMENTS}

This document will be the Work Planning Document for Development Control, (1999a).

Below is a list of requirements that must be identified in the work plan for any FacilityUse item per Developmental Control Requirements, (HNF 1999a). After each item is a description of where the information can be found.

- Description of the work to be performed

- Restrictions and/or special conditions

- Inspection/fabrication criteria

- Work Order Number

- Material Requirements

- Special Testing Requirements

- Safety Class
HNF-SD-WM-ETP-220, Rev 1, Sec. 3.0

None.

Fabrication Request (J-10) and HNF- SD-WM-ETP-220, Rev 1, Sec. 9.0

Fabrication Request (J-10)

Pre-released and released drawing

Data sets

HNF-SD-WM-ETP-220, Rev 1,

Sec. 3.7

Fabrication Request (J-10) 
- Approval Designator

- Shipping and Handling Instructions

- Delivery Date
Fabrication Request (J-10) and HNF-SD-WM-ETP-220, Rev 1, Sections 9,10

Fabrication Request (J-10)

Fabrication Request (J-10)

Characterization Engineering personnel shall have signature authority on any redline changes.

\subsection{CONFIGURATION MANAGEMENT}

Configuration management will comply with the requirements in engineering Drawing Requirements (HNF 1999e) and Engineering Document Change Control Requirements (LMH 1999a).

\subsection{QUALITY ASSURANCE}

Quality Assurance review of tasks will be determined on a task-by-task basis per Review and Approval of Documents (LMH 1999b). The cognizant engineer will assign approval designators for all documentation. All documents with approval designator " $Q$ " will be reviewed and signed by Quality Assurance (QA).

DynCorp, Tri-cities Services, Inc. Quality Control (QC) shall inspect all fabricated items and will qualify the assembly per the notes on released and pre-released drawings.

Fluor Daniel Hanford Quality Control (QC) shall inspect all installed items and will qualify the items per the notes on released and pre-released drawings.

\subsection{SAFETY AND AUTHORIZATION BASIS}

Safety review will be determined on a task-by-task basis per Review and Approval of Documents, (LMH 1999b). The cognizant engineer will assign approval designators for all documentation. All documents with approval designator " $\mathrm{S}$ " will be reviewed and signed by Safety.

No authorization basis or permitting documentation changes are anticipated, however, a Unreviewed Safety Question Screening/Determination will be completed on all changes made. 


\subsection{SYSTEM ENGINEERING}

This task plan defines the work required to provide routine engineering support for Characterization Sampling Operations. This subtask is covered under the Work Breakdown Structure (WBS) 1.01.01.01.01.03.01.09, with a CACN of 102250 and a COA of B000. Any major changes will be made to the WBS through the change request process (CR-TWRS-98-024).

\subsection{CLOSEOUT COSTS}

Closeout costs could vary, depending on when closeout occurred, but would be limited to less than 100 hours. The closeout costs could include time to ensure that partially completed datasets, ECNs, and work packages are placed in a retrievable condition. 


\subsection{REFERENCES}

DI, 1999a, DI-CE-009-00, Rev. 0, Engineering Service Request/Log Book, Lockheed Martin Hanford Corporation, Richland, WA

HNF, 1999d, HNF-IP-0842, Vol. IV, RPP Administration, Sec 3.12, Acceptance of Structures, Systems and Components for Beneficial Use, Lockheed Martin Hanford Corporation, Richland, WA

HNF, 1999b, HNF-IP-0842, Vol. IV, RPP Administration, Sec. 4.24, Design Verification, Lockheed Martin Hanford Corporation, Richland, WA

HNF, 1999e, HNF-IP-0842, Vol. IV, RPP Administration, Sec. 4.25, Engineering Drawings, Lockheed Martin Hanford Corporation, Richland, WA

HNF, 1999a, HNF-IP-0842, Vol. IV, RPP Administration, Sec. 4.27, Developmental Control Requirements, Lockheed Martin Hanford Corporation, Richland, WA

HNF, 1999c, HNF-IP-0842, Vol. IV, RPP Administration, Sec. 4.28, Testing Practices Requirements, Lockheed Martin Hanford Corporation, Richland, WA

HNF, 1999f, HNF-SP-1230, Rev. 2 Draft, Fiscal Year 2000 Multi-Year Work Plan, WBS 1.1, Lockheed Martin Hanford Corporation, Richland, WA

LMH, 1999b, LMH-PRO-233, Rev. 1, Project Hanford Policy and Procedure System, Review and Approval of Documents, Fluor Daniel Hanford, Inc., Richland, WA

LMH, 1999a, LMH-PRO-440, Rev. 1, Project Hanford Policy and Procedure System, Engineering Document Change Control Requirements, Fluor Daniel Hanford, Inc., Richland, WA 